\title{
Karakteristik Karkas Bandikut (Echymipera kalubu) di Kabupaten Manokwari
}

\section{Carcass Characteristics of Bandikut (Echymipera kalubu) in Manokwari Regency}

\section{Frandz Rumbiak Pawere* dan John Arnold Palulungan}

Jurusan Peternakan, Fakultas Peternakan, Universitas Papua, Manokwari, 98314, Indonesia

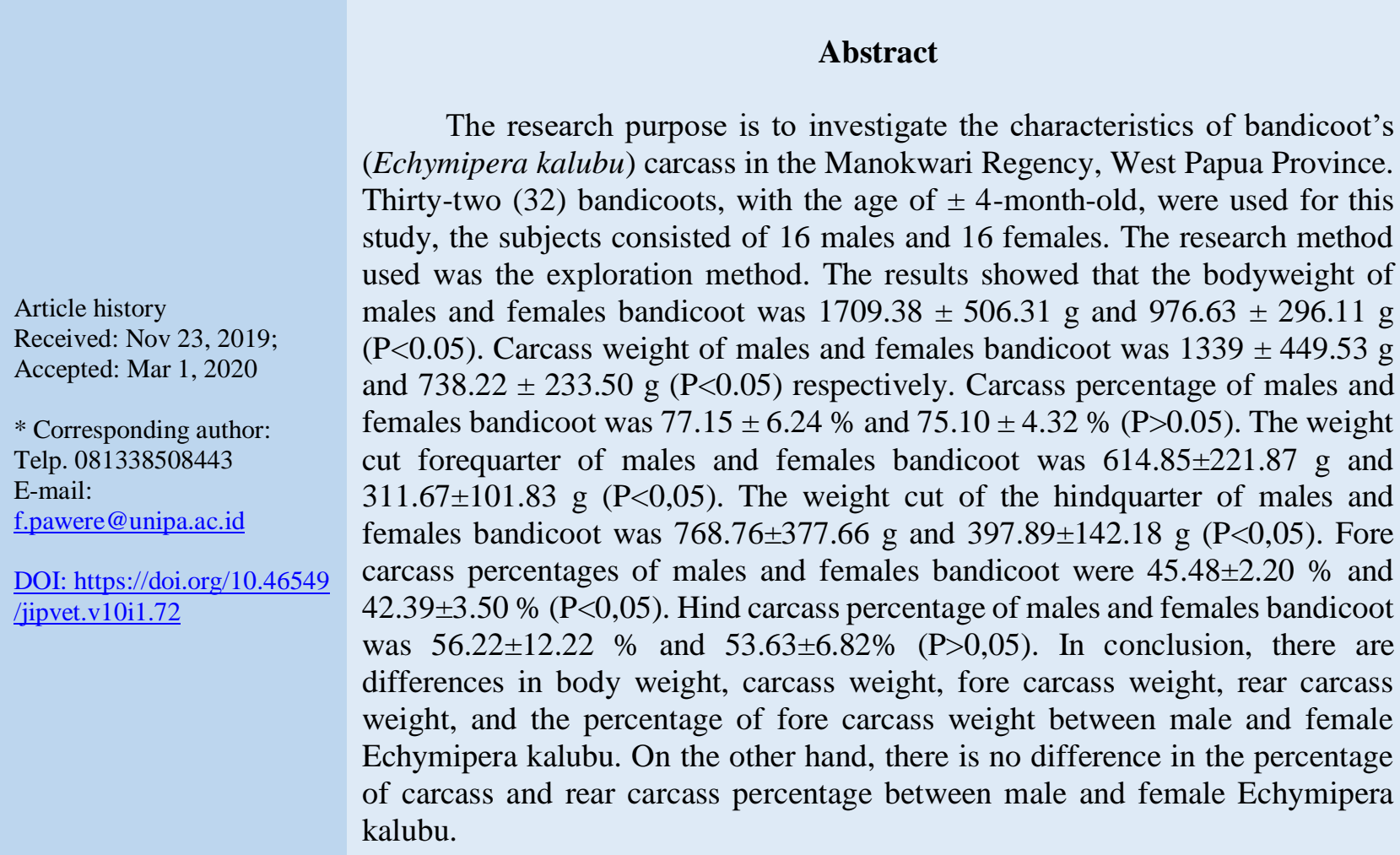

Keywords: Bandicoot; Carcass characteristcs; Echymipera kalubu

\section{PENDAHULUAN}

Pemanfaatan satwa sebagai sumber protein di Tanah Papua sudah lama berlangsung. Jenis satwa yang diburu oleh masyarakat beragam dan disesuaikan dengan kebutuhan konsumsi keluarga (Iriansul et al, 2018). Beraneka satwa yang dimanfaatkan sebagai sumber protein baik dari ungags dan mamalia. Dataran Lembah Prafi khususnya Kampung Macuan terdapat Burung Ayaman (Gallirallus philippensis) (Sada et al., 2018). Bandikut juga terdapat di daerah pesisir Kecamatan Manokwari Utara, Kabupaten Manokwari (Warsono dan Priyanto, 2011).

Bandikut tergolong dalam famili peroryctidae adalah salah satu kelompok mamalia marsupialia yang tersebar luas di Papua New Guinea. Sampai dengan saat ini baru 4 genus dan 11 jenis yang diketahui
(George dan Maynes, 1990; Flanery 1995a; Aplin, Helgen dan Lunde, 2010). Bandikut New Guinea adalah hewan terestrial dan omnivora yang memiliki bobot badan kurang lebih 2 kg (Seebeck et al., 1990) Microperoryctes papuensis (bandikut Papua) dan bandikut raksasa (Peroryctes broadbenti) masing-masing memiliki bobot badan $180 \mathrm{~g}$ sampai lebih dari $4 \mathrm{~kg}$ (Aplin dan Woolley, 1993; Aplin, Helgen dan Lunde, 2010). Habitat bandikut New guinea tersebar di padang rumput, hutan hujan tropis dan padang rumput di dataran rendah (Flannery, 1995a; Paliling, 2002). Echymipera kalubu adalah jenis bandikut yang merupakan hewan buruan masyarakat di Papua untuk dikonsumsi dagingnya. Kusrini (2001) menyatakan Tingkat konsumsi daging bandikut Echympera kalubu rata-rata 60 gram per kapita per hari per musim 
berburu dan hasil perburuan antara 1-10 ekor/sekali berburu (Unenor, 2001). Sementara masyarakat memperoleh bandikut dengan cara berburu untuk perdagangan eceran dan konsumsi sehari-hari. Bandikut dijual di pasar Wosi dan Sanggeng Manokwari dengan harga per ekor sebesar Rp 100.000,- sampai Rp. 200.000,-

Penelitian bandikut dari famili Peramelidae telah dilakukan di Australia (Seebeck et al,1990; Scott, Hume dan Dickman, 1999; Richards dan Short, 2003). Penelitian tentang perburuan bandikut telah dilakukan oleh Dwyer, (1985) dan Hide et al., (1984), penelitian tentang jejak bandikut telah dilakukan oleh Anderson et al., (1988); penelitian tentang organ reproduksi bandikut betina telah dilakukan oleh Fahry (2017) dan Reese (2001); penelitian tentang distribusi dan sejarah bandikut telah dilakukan oleh Huges et al., 1990; Aplin and Woolley, 1993; Flanney, 1995b). Komposisi kimia daging bandikut $E$. kalubu menurut Warsono (2009) adalah sebagai berikut. Kadar air $72.42 \%$, protein $18.72 \%$, lemak 3,26\%, serat kasar 4,43\%, abu 2,53\% dan energi $1090 \mathrm{kkal} / \mathrm{kg}$. Selain itu Persentase karkas E. kalubu sebesar $67.8 \%$ dengan ratio daging tulang sebesar 3.41:1. Pawere dan Saragih, (2019) menyatakan rata-rata bobot badan Echymipera kalubu jantan $1583.03 \pm 513.66 \mathrm{~g}$ dan rata-rata bobot karkasnya adalah $1214.95 \pm 432.33 \mathrm{~g}$. Informasi tentang karakteristik karkas Echymipera kalubu berupa persentase karkas depan dan belakang belum tersedia. Oleh karena itu, penelitian ini dilakukan untuk memberikan informasi baru tentang persentase karkas Echymipera kalubu bagian depan dan belakang.

\section{MATERI DAN METODE}

Penelitian ini dilakukan selama 3 bulan, yaitu dari bulan Februari-April 2019 di Kabupaten Manokwari.

Bahan yang diperlukan dalam penelitian ini adalah bandikut berjenis kelamin jantan dan betina masing-masing sebanyak 16 ekor di tangkap sendiri menggunakan perangkap. Status konservasi dari Echymipera kalubu adalah least concern artinya masih melimpah di alam. Ketersediaan bandikut di alam masih sangat melimpah. Pengunaan bandikut pada penelitian ini masih relatif sedikit sehingga tidak akan mengganggu keseimbangan alam. Alat yang digunakan dalam penelitian ini adalah senter kepala untuk berburu bandikut pada malam hari, timbangan duduk merk Weston kapasitas $2 \mathrm{~kg}$ graduation 10 gram, timbangan Prohex kapasitas $15 \mathrm{~kg}$ graduation 50 gram untuk menimbang bobot badan dan karkas bandikut, pisau cutter digunakan untuk memotong bandikut, kamera untuk dokumentasi, parang untuk pembuatan jerat bandikut, sepatu boot untuk melindungi kaki selama di hutan, sarung tangan bedah dipakai selama pembedahan, tali nelon $3 \mathrm{~mm}$ dan nelon ukuran 40 dijadikan sebagai tali jerat, dan alat tulis menulis.

Penelitian dilakukan secara eksplorasi, dimana menangkap bandikut dengan cara berburu dan menngunakan perangkap konvensional. Pada metode penelitian ini menggunakan 2 kelompok yang dibedakan berdasarkan jenis kelamin yaitu jantan dan betina masing-masing berjumlah 16 ekor.

Tahap persiapan meliputi beberapa langkah sebagai berikut: 1) Pengambilan data sekunder, 2) Mempersiapkan peralatan yang akan digunakan, 3) Mendapatkan bandikut dengan cara membuat perangkap pada siang hari dan berburu malam hari, 4) Pengambilan data primer

Tahap pelaksanaan penelitian meliputi beberapa langkah sebagai berikut: 1) Mendapatkan bandikut dengan cara memasang perangkap pada siang hari dan beburu pada malam hari, 2) Penimbangan bobot hidup bandikut sebagai bobot potong (g), 3) Penyembelihan bandikut. Proses penyembelihan sebagai berikut a) Penyembelihan bandikut dilakukan dengan cara memotong bagian leher dekat rahang bawah sehingga kulit, otot, vena jugularis, arteri karotis komunis, oesophagus dan trachea terpotong sempurna, b) Kepala dipotong pada sendi occipito-atlantis, c) Kaki depan/Kaki belakang dipotong dibagian carpal/tarsal, 3) Ekor dipotong tepat pada pangkal ekor (os ischii); 4) Penghilangan bulu bandikut dengan cara dibakar, 5) Pengeluaran isi rongga dada dan abdomen dengan cara menyayat diinding dada sampai anus kemudian isi rongga dikeluarkan, 6) Karkas segar yang diperoleh kemudian ditimbang untuk memperoleh bobot karkas (g). 7) Karkas segar dipotong menjadi 2 
bagian utama, yaitu Karkas bagian depan dan belakang yaitu batas vertebrae thoracalis 13 dan vertebrae lumbalis 1,8) Karkas depan dan belakang yang diperoleh kemudian ditimbang untuk memperoleh bobot karkas depan dan belakang $(\mathrm{g})$.

Variabel yang diamati dalam penelitian ini adalah: 1) Bobot karkas (g): dapat dihitung dengan menimbang bandikut yang sudah dipotong yang dikurangi dengan darah, kulit, kepala, keempat kaki isi rongga dada, dan isi rongga perut. 2) Persentase karkas (\%) atau Dressing Precentage adalah rasio antara bobot karkas dengan bobot hidup waktu disembelih dikalikan dengan $100 \%$, atau dapat disederhanakan sebagai berikut (Santosa, 2010):

$$
\% \text { Karkas }=\frac{\text { bobot } \operatorname{karkas}(g)}{\text { bobot potong }(g)} \times 100 \%
$$

3) Bobot potongan karkas bagian depan (g), berat bagian karkas yang terdiri dari sepasang kaki bagian depan, dada, hingga tulang iga 13. 4) Bobot potongan karkas bagian belakang (g), berat potongan karkas terdiri dari vertebrae lumbalis 1, loin, paha hingga sepasang kaki bagian belakang.

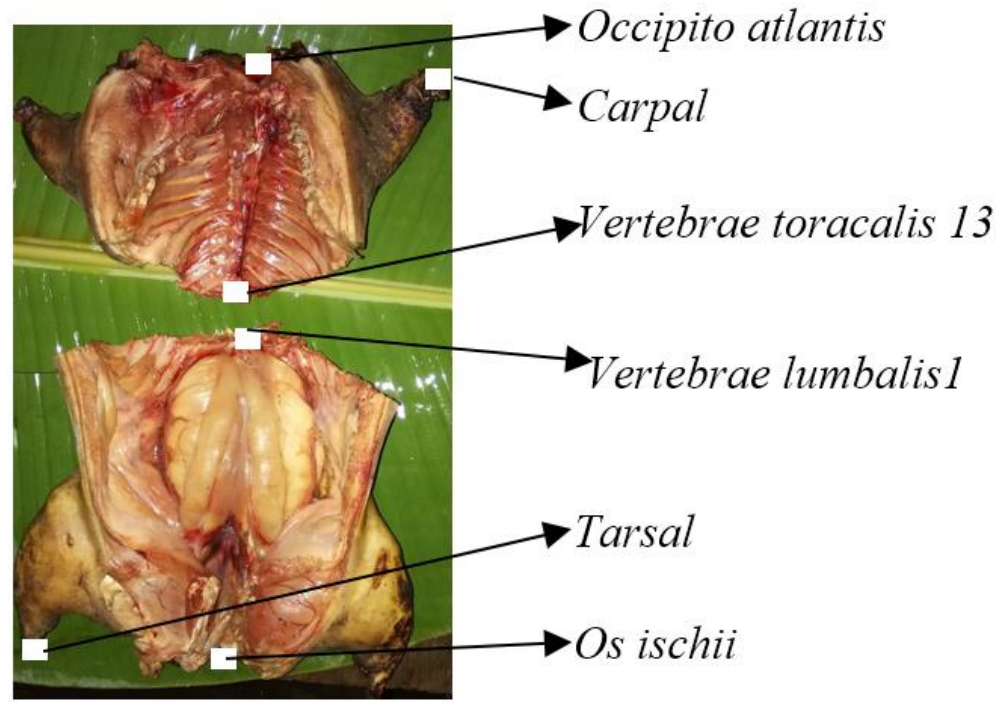

Gambar 1. Potongan karkas bandikut

Data yang diperoleh dianalisis dengan uji sampel bebas (Independent-Samples-T Test) untuk mengetahui apakah ada perbedaan nilai tengah (mean) dari bandikut jantan dan betina. Analisis data dibantu dengan software SPSS 24.

\section{HASIL DAN PEMBAHASAN}

\section{RATAAN BOBOT POTONG, BOBOT KARKAS DAN PERSENTASE KARKAS BANDIKUT}

Hasil penelitian tentang bobot potong, bobot karkas dan persentase karkas disajikan pada Tabel 1.

Tabel 1. Rataan bobot potong (g), bobot karkas (g), dan persentase karkas (\%)

\begin{tabular}{|c|ccc|}
\hline $\begin{array}{c}\text { Kelompok } \\
\text { bandikut }\end{array}$ & $\begin{array}{c}\text { Bobot potong } \\
(\mathbf{g})\end{array}$ & $\begin{array}{c}\text { Bobot karkas } \\
(\mathbf{g})\end{array}$ & Persentase karkas $(\%)$ \\
\hline Jantan & $1709,38 \pm 506,31^{\mathrm{a}}$ & $1339,00 \pm 449,53^{\mathrm{a}}$ & $77,15 \pm 6,24^{\mathrm{a}}$ \\
\hline Betina & $976,63 \pm 296,11^{\mathrm{b}}$ & $738,22 \pm 233,50^{\mathrm{b}}$ & $75,10 \pm 4,32^{\mathrm{a}}$ \\
\hline a,b & superskrip yang berbeda pada kolom yang sama menunjukkan perbedaan $(\mathrm{P}<0,05)$ & \\
\hline
\end{tabular}

Tabel 1. Menunjukkan terdapat perbedaan bobot potong dan bobot karkas antara bandikut jantan dan betina $(\mathrm{P}<0,05)$ tetapi persentase karkas tidak berbeda $(\mathrm{P}>0,05)$. Rataan bobot potong yang dihasilkan dari kelompok jantan dan betina berturut-turut adalah sebagai 
berikut: $1709,38 \pm 506,31^{\mathrm{a}}$ dan $976,63 \pm$ $296,11^{\text {b }}$. Bobot potong kelompok jantan lebih tinggi dibandingkan dengan kelompok betina $(\mathrm{P}<0,05)$. Diduga hal ini disebabkan oleh hormon androgen yang terdapat pada testis bandikut jantan. Androgen disintesis dan disekresikan ke dalam aliran darah dan sebagian besarnya membentuk testosteron. Setelah memasuki sel-sel targetnya, testosteron dimetabolisasi oleh $5 \alpha$-reductase menjadi $5 \alpha$ DHT pada banyak organ-organ reproduksi jantan (Bruchovsky \& Wilson, 1968). Dihydrotestosterone (DHT) merupakan androgen alami yang paling potensi yang berperan sangat penting dalam mendeterminasi diferensiasi seksual, perkembangan organorgan seks tambahan baik internal maupun eksternal serta berperan juga dalam perkembangan otot dan rambut pada sejumlah area (Lin dan Chang, 1997). Testosteron berperan penting dalam menstimulasi tingkah laku psikoseksual (psychosexual behavior) dan perkembangan ductus Wolffii, otot, spermatogenesis, dan pertumbuhan (ImperatoMcGinley et al., 1979). Warsono (2009) menyatakan bahwa bobot badan berkaitan erat dengan bobot karkas yang dihasilkan. Peningkatan bobot badan akan diikuti pula dengan meningkatnya bobot karkas. Menurut Forest et al., (1975) dan Berg and Butterfield
(1976), persentase karkas meningkat seiring dengan peningkatan bobot potong.

Bobot karkas bandikut jantan dan betina juga berbeda (Tabel 1), dan terdapat perbedaan $(\mathrm{P}<0,05)$ rataan bobot karkas bandikut jantan dan betina berturut-turut sebagai berikut $1339,00 \pm 449,53^{\mathrm{a}}$ dan 738,22 $233,50^{\mathrm{b}}$. Haryoko dan Titik (2008), menyatakan bahwa komponen karkas terdiri dari daging, tulang dan lemak. Hasil penimbangan menunjukkan bahwa semakin besar bobot badan maka akan dihasilkan bobot karkas yang tinggi pula. Bobot karkas menjadi salah satu hal yang menarik dalam karakteristik karkas. Bobot karkas sangat tergantung dari bangsa bandikut dan pakan. Warsono (2009) menyatakan bahwa konsumsi bahan kering bandikut dipengaruhi oleh banyak faktor yang saling berinteraksi diantaranya aspek anatomi, status fisiologi, bobot badan, kandungan nutrisi, dan palatabilitas pakan. Diduga bandikut mengkonsumsi pakan sangat dipengaruhi oleh beberapa faktor seperti komposisi kimia, jumlah kalori, bentuk fisik, palatabilitas, jumlah dan variasi makanan, bobot tubuh dan kondisi fisiologis yang baik.

Tabel 1 juga menunjukan bahwa persentase karkas bandikut jantan adalah $77,15 \%$ dan betina $75,10 \%$ dengan rataan $76,13 \%$, lebih tinggi dibandingkan dengan persentase karkas hewan lainnya.

\section{Tabel 2. Persentase karkas bandikut dan beberapa jenis ternak/hewan lain (\%)}

\begin{tabular}{|c|c|}
\hline Jenis hewan & Rataan \\
\hline Bandikut & $76,13 \pm 5,28$ \\
\hline Tikus hutan ${ }^{1}$ & $57,67 \pm 1,15$ \\
\hline Tikus budidaya $^{1}$ & $62,19 \pm 3,62$ \\
\hline Kancil $^{2}$ & 52,03 \\
\hline $\mathrm{Napu}^{3}$ & 59,31 \\
\hline Sapi Madura ${ }^{4}$ & $46,88 \pm 1,34$ \\
\hline Sapi Bali ${ }^{4}$ & $53,61 \pm 0,82$ \\
\hline Sapi Sumba Ongole 4 & $43,62 \pm 1.32$ \\
\hline Kambing kacang ${ }^{5}$ & 42,46 \\
\hline Kambing $\mathrm{PE}^{6}$ & 46,65 \\
\hline Domba $^{7}$ & 52,00 \\
\hline $\mathrm{Babi}^{7}$ & 72,00 \\
\hline Ayam pedaging $^{8}$ & 71,25 \\
\hline
\end{tabular}

Peningkatan sedikit ukuran tubuh dapat menyebabkan peningkatan secara proporsional dari bobot tubuh suatu ternak (Rao et al., 1978). Hasil penghitungan persentase karkas sejalan dengan hasil pengukuran terhadap bobot potong (bobot hidup) dan bobot karkas karena persentase karkas merupakan perbandingan antara bobot karkas dengan bobot hidup saat dipotong (dikurangi isi saluran pencernaan dan urin) dikali dengan 100\% (Santoso dan Sutarno, 
2010). Bobot potong mempengaruhi persentase karkas yang dihasilkan. Sumardianto et al., 2013, menyatakan bahwa semakin tinggi bobot potong maka persentase karkas semakin tinggi pula. fakta ini berarti bahwa bandikut kalubu dapat di jadikan hewan alternatif penghasil daging. Menurut Williamson and Payne (1993), pada umumnya satwa liar menghasilkan karkas dengan persentase lebih tinggi. Tingginya persentase karkas kelompok jantan dibandingkan dengan betina di duga disebabkan oleh bobot awal individu yang kemungkinan lebih berat. Risqiani (2011), menjelaskan bahwa ketika bobot awalnya lebih tinggi maka memungkinkan hasil bobot akhirnya lebih tinggi juga. Sumardianto et al., (2013) menyatakan bahwa semakin tinggi bobot potong maka pesentase karkasnya semakin tinggi pula.

\section{RATAAN BOBOT POTONGAN DAN \\ PERSENTASE KARKAS BAGIAN DEPAN DAN BELAKANG}

Hasil penelitian terhadap bobot karkas, bobot potongan karkas bagian depan, bobot potongan karkas bagian belakang, persentase karkas bagian depan, dan persentase karkas bagian belakang pada bandikut berdasarkan jenis kelamin disajikan pada Tabel 3.

Tabel 3. Rataan persentase karkas, potongan karkas bagian depan, potongan karkas bagian belakang, persentase bagian depan, dan persentase bagian belakang

\begin{tabular}{|c|c|c|c|c|c|}
\hline $\begin{array}{c}\text { Kelompok } \\
\text { Bandikut }\end{array}$ & $\begin{array}{c}\text { Bobot Karkas } \\
\text { (g) }\end{array}$ & $\begin{array}{c}\text { Potongan Karkas } \\
\text { Bagian Depan } \\
\text { (g) }\end{array}$ & $\begin{array}{c}\text { Potongan Karkas } \\
\text { Bagian Belakang } \\
\text { (g) }\end{array}$ & $\begin{array}{c}\text { Persentase } \\
\text { Bagian } \\
\text { Depan } \\
(\%)\end{array}$ & $\begin{array}{c}\text { Persentase } \\
\text { Bagian } \\
\text { Belakang }(\%)\end{array}$ \\
\hline Jantan & $1339,00 \pm 449,53^{a}$ & $614,85 \pm 221,87^{a}$ & $768,76 \pm 377,66^{a}$ & $45,48 \pm 2,20^{\mathrm{a}}$ & $56,22 \pm 12,22^{\mathrm{a}}$ \\
\hline betina & $738,22 \pm 233,50^{b}$ & $311,67 \pm 101,83^{b}$ & $397,89 \pm 142,18^{b}$ & $42,39 \pm 3,50^{\mathrm{b}}$ & $53,63 \pm 6,82^{a}$ \\
\hline
\end{tabular}

Tabel 3 menunjukan bahwa semua variabel yang diamati : bobot karkas, potongan karkas bagian depan, potongan karkas bagian belakang, persentase karkas bagian depan menunjukkan perbedaan nyata $(\mathrm{P}<0,05)$ kecuali persentase karkas bagian belakang yang sama. Hasil peneitian ini sama dengan hasil penelitian Warsono (2009) yang menyatakan bahwa potongan karkas kaki belakang bandikut lebih besar dari potongan karkas bagian depan terhadap bobot karkas yaitu sebesar 215,10 g dan 154,66 g. Hasil yang sama juga diperoleh pada penelitian ini. Selain itu juga karkas bandikut pada potongan bagian belakang lebih berat daripada potongan karkas pada bagian depan. Perbedaan berat ini disebabkan oleh otot di bagian karkas belakang lebih banyak dibandingkan bagian depan. Oleh karena itu, dapat disimpulkan bahwa dari sisi komersial daging bagian belakang bandikut lebih berat dibandingkan dengan bagian depan sehingga menjadi salah satu bahan pertimbangan konsumen.

\section{KESIMPULAN}

Bobot potong, bobot karkas, potongan karkas bagian depan, potongan karkas bagian belakang, dan persentase karkas bagian depan antara Echymipera kalubu jantan dan betina berbeda. Persentase karkas dan persentase karkas bagian belakang antara Echymipera kalubu jantan dan betina sama.

Perlu adanya penelitian lanjutan tentang kebutuhan bahan kering, energi, protein bandikut dengan menggunakan jumlah bandikut yang lebih banyak dan dibagi dalam kelompok bandikut besar, sedang dan kecil untuk masing-masing jenis kelamin. Hasil penelitian lanjutan akan membantu dalam upaya domestifikasi bandikut sebagai sumber protein masyarakat. Selain itu upaya penangkaran guna penelitian lanjutan perlu mengetahui kebutuhan pokok bandikut. .

\section{DAFTAR PUSTAKA}

Anderson, T. J., Berry, A., Amos, J., and Cook, J. 1988. Spool and line tracking of the New Guinea spiny bandicoots, E. kalubu. 
Journal of Mammalogy 69, 114-120. doi:10.2307/1381754

Aplin, K. P., and Woolley, P. A. 1993. Notes on the distribution and reproduction of the Papuan bandicoot Microperoryctes papuensis (Peroryctidae, Peramelemorphia). Science in New Guinea 19, 109-112.

Aplin, K.P.,Helgen,K.M., and Lunde,D.P. 2010. A review of Peroryctes broadbenti, the giant bandicoot of Papua New Guinea. American Museum Novitates 3696,1 -41. doi: $10.1206 / 3696.2$

Arifin. 2004. Kajian Produktifitas Dan Produk Napu (Tragulus Napu) Di Provinsi Jambi [Disertasi]. Bandung : Sekolah Pascasarjana, Universitas Padjadjaran.

Berg RT, And RM. Butterfield.1976. New Concepts Of Cattle Growth. Sidney University Press. Sidney.

Boggs DL, Merkel RA. 1984. Live Animal Carcass Evaluation And Selection Manual. $2^{\text {nd }} \quad$ Ed. Kendall/Hunt Publishing Company. Iowa.

Bruchovsky, N. And J.D. Wilson. 1968. The Conversion Of Testosterone To 5 Androstan-17 -Ol-3-One By Rat Prostate In Viwo And In Vitro

Damshik M. 2001. Produktivitas Kambing Kacang yang Mendapat Ransum Penggemukkan dengan Kandungan Protein yang Berbeda [Disertasi]. Bogor. : Sekolah Pascasarjana, Institut Pertanian Bogor.

Dwyer, P. D. 1985. A hunt in New Guinea: some difficulties for optimal foraging theory. Man 20, 243-253. doi: $10.2307 / 2802383$

Fahry. 2017. Morfometri Organ Reproduksi Bandikut (Echymipera kalubu) Betina.[Skripsi] Fakultas Peternakan Universitas Papua. Manokwari.

Flannery T. 1995a. Mammals of New Guinea. The Australian Museum.

Flannery T. 1995b. Mammals of The South West Pacific and Moluccan Islands. The Australian Museum.

Forrest JC, Aberle ED, Hendrick AB, Judge MD, Merkel RA. 1975. Principles of Meat Science. WH Freeman And Company. San Fransisco.
George, G. G., and Maynes, M. M. 1990. Status of New Guinea bandicoots.In'Bandicoots and Bilbies'.(EdsJ.H.,Seebeck,P.R.Brown, R. L. Wallis, and C. M. Kemper.) pp. 93105. (Surrey Beatty: Sydney.)

Haryoko. I. dan Titik Warsiti. 2008. Pengaruh Jenis Kelamin dan Bobot Terhadap Karateristik Fisik Karkas Peranakan New Zealand White. J Animal Production 2(10): $85-89$.

Hide, R. L., Pernetta, J. C., and Senabe, T. 1984. Exploitation of wild animals. In The Research Report of the Simbu Land Use Project.Vol.4, South Simbu. Studies in Demography, Nutrition and Subsistence.' pp. 291-380. (IASER: Port Moresby, Papua New Guinea.)

Imperato-McGinley, J., E.P. Ralph ., T. Gautier. and E. Sturla. 1979. Androgens and the Evolution of Male-Gender Identity among Male Pseudohermaphrodites with $5 \alpha$-Reductase Deficiency. N Engl J Med., 300: 1233-1237.

Iriansul, I., Warsono , I. A., \& Wajo , M. J. 2018. Kontribusi satwa dalam menunjang ketahanan pangan masyarakat Distrik Tembuni Kabupaten Teluk Bintuni. Cassowary, 1(2), 89-94. Retrieved from https://journalpasca.unipa.ac.id/index.php/ cs/article/view/12

Kusrini DS. 2001. Tingkat Konsumsi Daging Bandikut oleh Penduduk Asli dan FaktorFaktor yang Mempengaruhinya di Kecamatan Warmare.[skripsi] Faperta. Universitas negeri Papua. Manokwari.

Paliling A. 2002. Habitat Mencari Makan Bandikut di Desa Anjai Kecamatan Kebar. Kabupaten Manokwari. [skripsi] Faperta Universitas Negeri Papua. Manokwari.

Pawere F. R. P. 2019. The production Characteristics of Male Bandicoot (Echymipera kalubu). Buletin of animal science 43(2):1-5

Rao,. D. R, Sunki G.R, Johnson W.H, Chen C.P. 1978. Effect of Weaning and Slaughter Age on Rabbit Meat Productions II.Carcass, Quality and Composition. J Animal Sci 5: 578-582.

Reese N. 2001. Reproduction, Growth, Activity and Diet of Southtern Brown Bandicoots, 
Isoodon obesulus. Sth. Aust. Nat. Vol. 75, No. 34.

Richards, J. D., and Short, J. 2003. Reintroduction and establishment of the western barred bandicoot Perameles bougainville (Marsupialia: Peramelidae) at Shark Bay, Western Australia. Biological Conservation 109, 181-195. doi:10.1016/S0006-3207(02)00140-4

Rizqiani, Arifah. 2001. Performa Kelinci Potong Jantan Lokal Peranakan New Zealan White yang diberi Pakan Silase atau Ransum Komplit.

Rose SP. 1997. Principles of Poultry Science. London : CABI International.

Rosyidi D. 2005. Beberapa Aspek Biologi dan Karakteristik Karkas Kancil (Tragulus javanicus) [disertasi]. Bogor: Sekolah Pascasarjana, Institut Pertanian Bogor.

Sada, Y., Warsono, I., \& Murwanto, A. (2018). Sifat Kualitatif, Morfometrik, dan Karkas Burung Ayaman (Gallirallus Phillippensis) di Kampung Macuan Distrik Masni Kabupaten Manokwari. Jurnal Ilmu Peternakan Dan Veteriner Tropis (Journal Of Tropical Animal And Veterinary Science), $\quad 8(1), \quad 19 \quad-26$. doi:10.30862/jipvet.v8i1.30

Santoso, U dan Sutarno. 2010. Bobot Potong dan Karkas Kelici New Zealand White Jantan Setelah Pemberian Ransum Kacang Koro (Mucuna Pruriens Var. Utilis). Bioteknologi. 7(1):19-26.

Scott, L. K., Hume, I. D., and Dickman, C. R. 1999. Ecology and population biology of long-nosed bandicoots (Perameles nasuta) at North Head, Sydney Harbour National Park. Wildlife Research 26, 805-821. doi:10.1071/WR98074

Seebeck, J. H., Brown, P. R., Wallis, R. L., and Kemper, C. M. 1990. 'Bandicoots and Bilbies.' (Surrey Beatty: Sydney.)
Sumardianto. T. A., P. Endang dan Masykuri. 2013. Karateristik Karkas Kambing Peranakan Etawa dan Kambing Kejabong Jantan Pada Umur Satu Tahun. J. Animal Agriculture. 1(2) :175 - 182.

Tien-Min, L. and C. Chang. 1997. Cloning and Characterization of TDD5, an Androgen Target Gene That Is Differentially Repressed by Testosterone and Dihydrotestosterone. Proc. Natl. Acad. Sci. USA., 94: pp. 4988-4993.

Unenor E. 2001. Teknologi Perburuan Bandikut oleh Suku Hatam di Oransbari. [skripsi] Faperta Universitas Negeri Papua. Manokwari.

Wahyuni I. 2005. Tingkah Laku, Reproduksi, dan Karakteristik Daging Tikus Ekor Putih (Maxomys hellwandii) [Disertasi]. Bogor: Sekolah Pascasarjana, Institut Pertanian Bogor.

Warsono ,IU. dan Priyanto, R. 2011. Sifat Biologis Dan Karakteristik Karkas Bandikut (Echymipera kalubu). Berk. Penel. Hayati Edisi Khusus: 4B (13-19). https://berkalahayati.org/files/journals/1/ar ticles/140/submission/review/140-398-1RV.pdf

Warsono IU. 1994. Evaluasi Performa Karkas dan Daging Beberapa Bangsa Sapi Lokal (Madura, Bali, Dan Sumba Ongole) [Tesis]. Bandung: Program Pascasarjana, Universitas Padjadjaran.

Warsono IU. 2009. Sifat Biologis dan Karakteristik Karkas dan Daging Bandikut (Echymipera kalubu). [Disertasi] Pasca Sarjana. Institut Pertanian Bogor.

Williamson G, and Payne WJA. 1993. Pengantar Peternakan di Daerah Tropik. Gadjah Mada University Press. Yogyakarta. 